\title{
Economics
}

2015; 4(2): 22-33

Published online March 25, 2015 (http://www.sciencepublishinggroup.com/j/eco)

doi: 10.11648/j.eco.20150402.12

\section{The Effect of Monetary Policy on the Private Sector Investment in Ethiopia: ARDL Co-Integration Approach}

\author{
Demilie Basha Hailu ${ }^{1}$, Fikru Debele ${ }^{2}$ \\ ${ }^{1}$ Department of economics, Adigrat University, Adigrat, Ethiopia \\ ${ }^{2}$ Department of economics, Arbamincth University, Arbamincth, Ethiopia
}

Email address:

demilie604@gmail.com (D. Basha), fikru.de@gmail.com (F. Debele)

\section{To cite this article:}

Demilie Basha Hailu, Fikru Debele. The Effect of Monetary Policy on the Private Sector Investment in Ethiopia: ARDL Co-Integration Approach. Economics. Vol. 4, No. 2, 2015, pp. 22-33. doi: 10.11648/j.eco.20150402.12

\begin{abstract}
Even though there is a belief that monetary policy can influence private sector investment, research works have not yet been conducted on the dynamic impact of monetary policy on private investment in Ethiopia. Rather, literatures are substantially deal with the determinants of private investment and the effectiveness of monetary policy in Ethiopia separately. Consequently, a times series analysis technique using annual data for the period 1975-2011 is utilized to investigate the power of policy makers in enhancing the performance of private investment through monetary policy changes. Moreover, the ambiguous results in relation with the power of monetary policy in affecting private sector investment in elsewhere including sub-Saharan countries become an initiation to undertake this particular study. Accordingly, this study seeks to present an empirical assessment of monetary policy that has either stimulated or dampened private sector investment for the past several decades. Employing time series econometric techniques such as, co-integration and error correction techniques within an ARDL framework the study reveals intriguing results. Results suggest that private investment is positively and significantly influenced in the short-run by public investment, money supply, and a real output but negatively and significantly by real exchange rate while, real interest rate is found to have insignificant and has a negative sign in line with macro-economic theory. Moreover, in the long run, the result shows a positive and significant effect of public investment, real GDP and broad money supply while real exchange rate negatively and significantly influenced private investment. However, real interest rate is found to have a positive but insignificant effect in the long run as well. The conclusion is that monetary policy measures are more influential than fiscal policy in promoting private investment in Ethiopia via improving financial resource availability for investment.
\end{abstract}

Keywords: Monetary Policy, ARDL Co-Integration, Private Investment, Ethiopia

\section{Introduction}

Government policies are crucial in determining the rate of economic growth, the levels of private investment and the magnitude of credit to the private sectors. Accordingly, Economists view monetary policy as the first line of defense against economic slowdowns via influencing growth of aggregate demand and the economy. For example, Angeloni(2003) shows that a change in the federal funds rate can set off a chain of events that will affect short-term interest rates, longer-term interest rates, the foreign exchange value and stock prices. In turn, changes in these variables will affect households' and businesses' spending decisions, thereby affecting growth in aggregate demand and the economy (Angeloni, 2003).Moreover, the study by Ayemere
(2010) shows that greater reliance can be placed on monetary policy as a veritable instrument for correcting some of the major macro-economic ills facing the economy.

Theoretically, monetary policy is expected to be a complement to the private sectors via using either of the following mechanisms. The first is controlling the amount of money in circulation, whether this involves literally printing money, or more technical measures such as quantitative easing, which involves creating money in the form of credit. The second measure is using interest rates to influence what people and businesses men pay to borrow or receive for saving, which can affect their spending and investment levels. The third measure is attempting to influence the exchange rate between the national and foreign currencies, which can involve fixing, or restricting exchange rates, or buying and selling currency to influence the market rate (Handa, 2009). 
However, one could see that there are conflicting results concerning the power of monetary policy in influencing private investment. For instance, Olweny (2012), Alexander (2011), chichi (2011), Godwin (2010), Bruno (2001), Asante, (2000) in one or the other round advocate that monetary policy specifically money supply strongly influenced private investment. Moreover, Liang and Huang (2011) advocate in favor of the traditional IS-LM and AD-AS results which has implication of real effect of money supply on output with sticky price in the short run.

Nevertheless, there are reports against the effectiveness of monetary policy. For instance, Alatiqi (2008) discovered that absence of a stable negative causal relation from money supply to interest rates, and from interest rates to stock prices, results in no significant long-term causal relation from money supply to stock prices. Moreover, Ezie (2012) is on the side of monetary policy ineffectiveness which shows that the increase in broad money supply could potentially encourage private sector investments in the tertiary sector at the detriment of the primary sector. Accordingly, nominal interest rates, nominal exchange rates and broad money supply as determinants of private sector investment are all poor, thus indicating that the monetary policy measures had no significant impact on private sector investment. Additionally, there is an argument stating that effectiveness of monetary policy depends on developments of financial markets and thus in sub Saharan African countries, with under developed financial market; monetary policy is ineffective (John, 2010).

However, William, (2004) showed that monetary policy actions have ambiguous effects on fixed investment activity. This is because changes in the level of interest rates affect both the present value of cash flows (through the discount rate) and the value of waiting to invest (through the real option consisting of timing). On the one hand, lower interest rates at all maturities would increase the present value of future cash flows, increasing the incentive to invest. On the other hand, it also implies a lower opportunity cost of waiting to invest due to the lower short term rate. In effect, the urgency to make a decision declines. Thus, monetary policy actions might increase uncertainty about future real interest rates. This could make the option to wait even more valuable (William, 2004).

In Developing countries' economy including Ethiopia, public investment is dominant whereas the private investment is in its nascent stage of development. Such as, Asrat (2012) shows that developing countries' domestic saving rate and hence private investment is observed to be extremely low.

The Ethiopian economy is manifested by different economic reforms and structural changes in respective regimes. For instance, following the revolution a number of reforms have been undertaken. Accordingly, the government brought large scale agricultural farms, industries, financial institutions etc under its direct control. In such a way the central bank controls monetary policy variables on behalf of the government. Moreover, the proclamation issued in 1975 was aimed at to insist the people to invest on enterprise larger than cottage industries. But, it is not hidden for everyone that the contribution of the private investment was insignificant.

Since the start of economic reform of 1991, Ethiopia has embarked on policies that aim to rebalance the role of public and private sector in the economy and thus emphasize private sector development. This is a major departure from the socialist policies of dergue period that relied heavily on public sector institutions.

However, In Ethiopia, both fiscal and monetary policies seem to be ineffective during the respective regimes. For example, during the command economy, as shown in the study of Mongbay (2010), in the 1980s the government adopted a conservative fiscal management as well as price control and official over valuing of birr to curb inflation but inflation was averaging $7.1 \%$ annually which is turned up during 1990 due to war expenditure.

Moreover, currently monetary policy seems aimed at increasing the amount of cash for banks available for lending. For instance, Davison (2012) shows that the national bank of Ethiopia cut the minimum ratio of deposit to be held in reserve to $10 \%$ from $15 \%$, and also the amount of liquid asset to be held as a proportion of deposits was also reduced to $20 \%$ from $25 \%$.However, lending to exporters and other business declined after the central bank issued a directive ordering to force banks to buy government securities equivalent to $27 \%$ of their total loans to fund infrastructure projects in each month (Davison, 2012).However, such restrictions on lending to private industry seems a restraint to growth of these sectors. Therefore, given the free market and privatization policy and ambiguous effect of monetary in elsewhere, studying the relative power of monetary policy in influencing the private sector is intuitive in the Ethiopian economy.

As to the researcher's knowledge, the previous studies have dealt separately with monetary policy and private sector investment but not linked the two in a dynamic framework. Such as Sisay (2007), Getinet (2005) and Daniel (2008) explicitly analyze the determinants of private investment in Ethiopia. Whilst Abebe (2008), Tadesse and Tekie (2012) are arguing the effectiveness of monetary policy in the Ethiopian economy. Moreover, Sengonzi (2009), Bajide (2011) and Misati (2010) focused on how various monetary and fiscal components crowd out private sector in studies using panel series data from several countries.

Based on this understanding, it is clear that there exists a gap in literature with regard to understanding the dynamics of monetary policy effects on private sector investment suggesting the need for research that would decompose and analyses facets of monetary policy supportive of private sector investment in Ethiopia. Implicitly the critical question posed in the study is whether monetary policy can be held accountable for private sector investment performance or the lack of it. Therefore, Unlike studies that focus on one aspect of either monetary or private sector investment, this study takes a dynamic approach to show the effect of monetary policy on private sector investment. In doing so what possible relation could exist between monetary policy 
variable and private investment in Ethiopia was testable statement.

\subsection{Objectives of the Study}

The paper investigates the effect of monetary policy on private investment in the case of Ethiopia. While addressing this general and broad objective, the study analyses the following specific objectives;

- Investigate the direction and magnitude impact of money supply on private investment both in the short run and long run.

- Analyze the behavior and response of private investment to changes in real interest rate both in the short run and long run.

- Analyze the Trends of private investment in Ethiopia.

\subsection{Model Specification}

\subsubsection{Theoretical Model Specification}

Different literatures argued that a simple accelerator model is a convenient and suited to develop a model for private investment. Moreover, Fikru (2007), Rufus (2008), Alexiadis and Daniel (2012) argued that private investment follows a simple accelerator model. In doing so, in the long run the model follows a general form which shows how private investment adjusts to the desired level of capital stock. Accordingly, the actual stock of private capital is assumed to adjust to the difference between the desired capital stock in period $\mathrm{t}$ and the actual stock in the previous period $\mathrm{t}-1$ :

$$
P I_{t}=\beta\left(K_{t}^{*}-K_{t-1}\right), \text { where, } \quad 0 \leq \beta \leq 1
$$

$\beta$ - Coefficient of adjustment which shows lag of implementation or other factors threaten the business people concerning the business climate.If $\beta=1$, then there is instantaneous adjustment of capital stock to its desired level and if $\beta=0$ no adjustment takes place at all. However, Rufus (2008) assumes a linear formulation of the desired capital stock as well as stable adjustment coefficient $(\beta)$.

On the basis of difficulties with the concept and measurement of the capital stock, the above equation is difficult to use for empirical analysis (Rufus, 2008). Therefore, to overcome such difficulties, one can represent the desired capital stock as; $K_{t}^{*}=\alpha_{i} Z_{t}$ (Fikru, 2007). Where, $Z_{t}=\sum_{t=1}^{n} X_{t}$ in which $X_{t}$ is a vector of variables affecting private investment. Then, first differencing of the simplified equation results in;

$$
\begin{aligned}
& P I_{t}=\alpha \beta\left(Z_{t}-Z_{t-1}\right)+(1-\beta) P I_{t-1} \\
& P I_{t}=\mu\left(Z_{t}-Z_{t-1}\right)+(1-\beta) P I_{t-1}
\end{aligned}
$$

Where, $\mu=\alpha \beta$

Since, by definition $P I_{t}=K_{t}-K_{t-1}$

Hence, from equation (2) $Z_{t}$ incorporates all factors that are responsible in determining private investment. Moreover, from the simple accelerator model, the desired capital stock is proportional to the level of output and can be written as;

$$
K_{t}^{*}=\alpha Y_{t}=\alpha Z_{t}
$$

\subsubsection{Econometrics Model Specifications}

Therefore, one can use equation (3) to specify that private investment not only as a function of the desired level of capital stock but also of a number of variables. Consequently, the simple accelerator model is going to be adjusted so as to incorporate determining factors of private investment. Bruno, (2001), Imtiaz, (2010) and Asante, (2000), reveal that the variables of most important in determining private investment levels are: domestic output, the real interest rate, public investment, credit available for investment, and exchange rate. Moreover, in one hand or other round, economists Such as, Maganga (2012), Ouattara (2010) and Karagoz (2010) argue that real GDP, public investment, domestic credit to private sector, real interest rate, real exchange rate and macroeconomic uncertainty variables are the major ones in determining private investment. Therefore, incorporating the aforementioned variables, the study is delimited on explanatory variables of: real exchange rate, domestic credit to private sector; real GDP, real interest rate, inflation and government expenditure (public investment) as a control variable.

Since monetary policy is the management of money and interest rates hence it has to be proxied by either money supply or interest rate operating targets. Accordingly, the central bank can manage the money supply-that is, conduct monetary policy, in three ways: By changing the monetary base through open market operations, through discount lending and by changing the money multiplier via the required reserve ratio.

Moreover, Central banks may exercise control over interest rates as their monetary policy instrument and letting interest rate exogenous. If the money supply is used as the primary instrument, the economy's interest rates will change in response to the central bank's changes in the money supply, and will be endogenous. If the interest rates are used as the primary monetary policy instrument, the economy's money demand will change in response to the changes in interest rates. In this case, the money supply will become endogenous. While the choice between the money supply and the interest rates can be trivial under certainty and a stable moneydemand function, it is not likely to be trivial under uncertainty and an unstable money-demand function, so that central banks are forced to make choices between the two alternatives. However, the standard assumption of monetary analysis is that the central bank exercises control over the economy by exogenously controlling the money supply. In this case, the appropriate analysis of aggregate demand is called IS-LM analysis. However, for certain types of economies, controlling the economy's interest rate may be a surer way of controlling aggregate demand than its money supply.

Generally, there seems a debate among researchers in allocating the proxies to monetary policy and to use either money supply or interest rate instrument primarily as operating targets. For instance, Nouri (2011), Chichi (2011), Dickinson (2005) and McCallum (1999) use broad money supply as a proxy to monetary policy operating targets. 
However, Handa (2009) shows that the central banks of several developed economies, including those of the United States, Canada and Britain, now seem to rely more on the interest rate rather than on the money supply as the primary monetary policy instrument. In line with this, in financially developed economies, the central banks believe that interest rates are a major indicator of the performance of the economy and tend to use them as the preferred guide and operating target of monetary policy. Thus, The central bank's policy actions on the monetary base immediately affect the commercial banks' demand and supply of reserves, thereby changing the overnight interest rate and starting a chain of reactions on other interest rates and thereby on borrowing and lending, investment and consumer spending, etc., in the economy.

Nevertheless, Jayaraman, (2008), shows that the interest rate channel is less effective in developing nations especially in sub Saharan African countries because money and capital markets are at nascent stages of development. Thus, broad money supply is powerful and becomes an important conduit of monetary policy shocks. Since changes in broad money supply immediately affects bank's balance sheets and bank's liability in which ultimately influencing private sector through bank credit. Moreover, chichi (2011), argues that money supply is found to be effective monetary policy instrument than interest rate, because private investment reacts more to changes in money supply than interest rate does. Therefore, for this particular study broad money supply M2 (the sum of currency in circulation, checkable account and money held in saving or deposit account) is taken as a proxy for monetary policy.

Hence, from the theoretical and empirical reviews, the model can be developed as;

$$
P I_{t}=\mathrm{f}\left(D C P_{t}, R_{t}, P U I_{t}, R E X_{t}, R G D P_{t}, M S_{t}, I F_{t}\right)
$$

Where, $D C P_{t}$ - domestic credit to private sector

$I F_{t}$-Inflation rate in $\mathrm{t}$ time period.

$R_{t}$ - Real interest rate

$R E X_{t}$ - Real exchange rate

$R G D P_{t}$ - Real gross domestic product

$M S_{t}$ - Money supply (M2)

$\mathrm{PUI}_{t}$ - Public investment.

Note that the explicit model can be formulated via considering the model (equation 5) is to be in multiplicative form. Since there are papers which assume that explanatory variables are in multiplicative form in the model of investment. Such as Magnus (2010) shows determinants of private investment following similar fashion. Moreover, to make the model estimable as well as to obtain elasticity coefficients, one could take natural logarithm to both sides.

Therefore, taking natural logarithm to both sides, the explicit estimable econometric model can be written as;

$$
\begin{aligned}
\ln P I_{t}= & \beta_{0}+\beta_{1} \ln D C P_{t}+\beta_{2} \ln P U I_{t}+\beta_{3} R_{t}+\beta_{4} \ln R E X_{t}+ \\
& \beta_{5} \ln R G D P_{t}+\beta_{6} \ln M S_{t}+\beta_{7} I F_{t}+\varepsilon_{t}
\end{aligned}
$$

Where, ln - denotes natural logarithm and all variables are in natural logarithm except real interest rate and inflation rate because, for inflation rate and real interest rate there are negative values in the data set.

$\beta_{i}-$ Measure impact response of private investment to each of explanatory variables or represent constant elasticity and

$\varepsilon_{t}$-Error term (disturbance term)

Domestic credit is expected to minimize the financial constraints of investors and also the complaints from the private sector about credit unavailability, all together gives a hint to expect a positive relationship with private investment. This could be seen in the study of Chibber and Monsoor (2001) where domestic credit is found to have a positive effect on private sectors investment.

Theoretically, the effect of public investment on private investment is ambiguous. While government investment in infrastructure is expected to be complementary to private investment, government investment in non-infrastructure may compete with private investment especially if the government competes with the private sector for funds or in the product market. Thus the effect of public investment on private investment is ambiguous. The empirical evidence is provided by Blejer and Khan (1999) in which the result shows that government investment in infrastructure is complementary to the private sector whereas noninfrastructural investment expenditures are not.

The sign of the real interest rate is an empirical issue but as it is the opportunity cost of investment, probably it would affect private investment negatively. Moreover, the effect of the real exchange rate on private investment is ambiguous. Genevesi (1997) argues that a real depreciation acts as an adverse supply shock in the "production" of investment goods. In the short run, a real depreciation will raise the price of new capital goods in terms of home goods (if capital goods have an import content) and this will tend to discourage new investment. In the case of foreign-indebted firms, depreciation raises the burden of debt; if domestic credit markets are imperfect (as is often the case in developing countries) these firms may face credit constraints, and this will tend to reduce investment.

Devaluation may also affect investment through its effect on aggregate demand as suggested by Manuel (1998). Accordingly, if the net effect is contractionary, then the slump in economic activity is likely to lead to a reduction in investment. However, if the net effect is expansionary, devaluation may raise real incomes and stimulate investment. Devaluation may affect the real price of imported inputs that are used in conjunction with capital goods to produce output, and may also affect interest rates, which in turn will affect private investment. The net effect of these factors cannot be determined a priori. Even if short-run effects of depreciation are negative due to increases in the real costs of imported capital and inputs, the long-run effects may still be positive.

Consistent with empirical works of elsewhere such as Greene (2000), Real GDP which captures the market potential or market demand is expected to affect private investment positively in this research work. While inflation has an ambiguous impact because in one way it affects real value of savings and investment returns. Especially, inflation can be harmful to fixed income returns. For instance, Michelle (2002) shows that inflation has a significant and 
negative effect on real value of fixed investment returns. Many investors buy fixed income securities because they want a stable income stream, which comes in the form of interest, or coupon, payments. However, because the rate of interest, or coupon, on most fixed income securities remains the same until maturity, the purchasing power of the interest payments declines as inflation rises(Michelle,2002).

However, Hall and Hitch (1989) argued the complementarity effect of inflation. They show that the most significant effect of inflation is its effect on the revenues of the government. When inflation is higher than previously thought and planned with, the revenues of the government increases, which is good as the budget balance of the government improves. The reason why revenues of the government increases when inflation increases, is because the government has higher tax revenues. Thus, expenditure on infrastructures would improve which has a complementary effect on private investment. But we expect that the wide adverse effect of inflation outweigh the positive effect as the share of private investment exceeds the public sector investment. Thus all this together lead us to expect a negative sign for coefficient of inflation for this particular research work.

Monetary policy has impact on financing conditions in the economy (via influencing the availability of credit) and also it influences expectations about economic activity and inflation. Consequently, monetary policy can affect the prices of goods, asset prices, exchange rates as well as consumption and investment. For instance, an expansion of the money supply by the central bank leads to improving the availability of credit to private sectors by letting banks to have liquid assets and a reduction of short-term market rates. As a result, the real interest rate and capital costs decline, raising investment. Additionally, consumers save less and opt for current consumption over future consumption (Olweny, 2012). This, in turn, causes demand to strengthen. Thus, the change in money supply would have a positive impact on private investment.

\section{Result and Discussion}

\subsection{Diagnostic Tests}

Table 2.1. Unit root test (test of stationarity).

Before proceeding to empirical results, linear relationship (muliticollinearity) test has been conducted. Thus, as shown in the first table of the appendix, domestic credit to private sector is highly correlated with money supply and real GDP(with correlation coefficient of 94\% and 92\% respectively) and hence domestic credit is dropped from the model. Moreover, we observe a high correlation between inflation and GDP as well inflation with real interest rate thus, inflation is also excluded for further investigation.

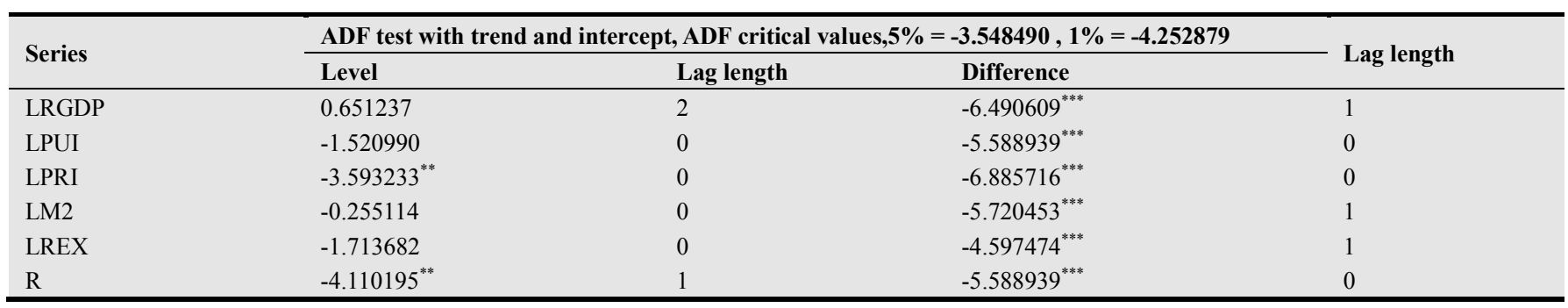

Notes: The null hypothesis is that the series is non-stationary, or contains a unit root. *** (**) denotes the rejection of null hypothesis of unit root at the $1 \%$ and 5\% significance levels respectively. The lag length in the Augmented Dicky Fuller (ADF) test is based on the Akaike Information Criterion (AIC). All results are obtained from Eviews 5.1 econometric package. All variables are in logarism except real interest rate(R), thus L- stands for logarism.

From the table shown above, real interest rate and private investment are stationary at level at $5 \%$ level of significance $\mathrm{I}(0)$ while the rest are stationary at their first difference $\mathrm{I}(1)$. Therefore, one can not apply the traditional cointegration tests of Engle and Granger (1987) as well as Johansen (1995) cointegration tests. However, this problem can be removed by using the ARDL bound test approach which is developed by Pesaran et al (2001) to observe the long run relationship among the variables. Thus, the cointegration method used here, the ARDL method, allows testing for a long-run relationship between variables of mixed order of integration (Pesaran et al., 2001).

Having established the integration order of the variables that enter the private investment model, this section will go a step further in trying to determine the maximum number of cointegrating vectors that appropriately span the variables. Since the selection of the lag length is important in estimating the ARDL regression, the test run over 3 lag length of 1, 2 and 3 to determine the optimal lag length. On the basis of AIC and Schwarz Bayesian criteria (SBC), ARDL model of order two was found to be the most appropriate in carrying out the cointegration test. Because, both AIC and Schwarz criteria accounts minimum value (as shown in the table below with corresponding value of -3.44 and -2.13 respectively for AIC and Schwarz criteria or largest log likelihood value of 85.84) when two lag length has been used for each variables. Thus, lag length of 2 is selected to proceed to the next step in this study.

Table 2.2. Determination of lag length to the ARDL cointegration model.

\begin{tabular}{llll}
\hline Models lag length & AIC & Schwarz criterion & Log likelihood value \\
\hline One & -1.99 & -1.19 & 52.85 \\
Two & -3.44 & -2.13 & 85.84 \\
Three & -2.43 & -1.40 & 64.28 \\
\hline
\end{tabular}


Table, 2.2. shows that the smallest value of AIC or the largest log likelihood value is obtained when the lag order of two is used. Therefore, the private investment model would be tested to check existence of long run association of variables using ARDL cointegration approach at lag two.

\subsection{Cointegration Test}

We start this empirical exercise by first establishing if there exists a long run association among variables of interest. Bound testing procedure developed by Pesaran (2001) is used for this purpose. This is considered essential as evidence of cointegrating relationship rules out the possibility of spurious regression. Bound testing procedure performs well in studies that have small sample size. Furthermore, instead of imposing restriction and deciding on the dependent variable, the ARDL method distinguishes between dependent and independent variable through usual F-tests. Moreover, as noted by Narayan (2004), the unrestricted equilibrium correction model is likely to have superior statistical properties compared to Engle-Granger method, as it does not push short run dynamics into the residual terms (Pattichis 1999). In order to test for cointegration using bounds testing procedure, firstly estimated the following unrestricted error correction model using ordinary least squares.

$$
\Delta Y_{i t}=\beta_{0}+\beta_{1} Y_{i t-t}+\beta_{2} X_{i t-1}+\sum_{i=1}^{\rho} \beta_{i} \Delta Y_{i t-1}+\sum_{j=0}^{m} \beta_{j} \Delta X_{i j-1}+\varepsilon_{t}
$$

Where, $Y_{i t}$ and $X_{i t-1}$ indicates vectors of variables in which, $Y_{i t}$ represents a vector of dependent variables and $X_{i t}$ a vector of independent variables at the same time. Moreover, $\Delta$ shows a difference operator. Or equivalently, the model can be developed as follows:

$$
\left[\begin{array}{c}
\Delta p_{t} \\
\Delta l p u i_{t} \\
\Delta r_{t} \\
\Delta r e x_{t} \\
\Delta r g d p_{t} \\
\Delta m s_{t}
\end{array}\right]=\left[\begin{array}{llllllllllll}
1 & 1 & 1 & 1 & 1 & 1 & 1 & 1 & 1 & 1 & 1 & 1 \\
1 & 1 & 1 & 1 & 1 & 1 & 1 & 1 & 1 & 1 & 1 & 1 \\
1 & 1 & 1 & 1 & 1 & 1 & 1 & 1 & 1 & 1 & 1 & 1 \\
1 & 1 & 1 & 1 & 1 & 1 & 1 & 1 & 1 & 1 & 1 & 1 \\
1 & 1 & 1 & 1 & 1 & 1 & 1 & 1 & 1 & 1 & 1 & 1 \\
1 & 1 & 1 & 1 & 1 & 1 & 1 & 1 & 1 & 1 & 1 & 1
\end{array}\right]\left[\begin{array}{c}
b_{0} p_{t-1} \\
b_{1} p u i_{t-1} \\
b_{2} r_{t-1} \\
b_{3} r e x_{t-1} \\
b_{4} r g d p_{t-1} \\
b_{5} m s_{t-1} \\
\sum_{t=1}^{m} \beta \Delta p_{t-1} \\
\sum_{t=0}^{m} \gamma \Delta l p u i_{t-1} \\
\sum_{t=0}^{m} \mu \Delta r_{t-1} \\
\sum_{t=0}^{m} \partial \Delta r e x_{t-1} \\
\sum_{1=0}^{m} \propto \Delta r g d p_{t-1} \\
\sum_{t-1}^{m} C \Delta m s_{t-1}
\end{array}\right]+\left[\begin{array}{c}
v_{1 t} \\
v_{2 t} \\
v_{3 t} \\
v_{t t} \\
v_{5 t} \\
v_{6 t}
\end{array}\right]
$$

Where, variables are in logarisms except real interest rate.

Since multiplying any number or matrix by one does not bring any significant changes and thus as shown in the above to simplify the representations, the study used to form a matrix by multiplying a singular matrix.The computed Fstatistics from the test is then compared with critical value from pesaran (2001). If the computed F-statistics exceeds upper bound critical value, then the null hypothesis that there is no long run relationship can be rejected at $1 \%$ significance level.

Table 2.3. Cointegration tests using a bound test at 10\%, 5\% and 1\% level of

\begin{tabular}{|c|c|c|c|c|c|c|}
\hline \multicolumn{7}{|c|}{ Critical values bounds of F-statistics; with intercept and trend } \\
\hline \multicolumn{3}{|c|}{$10 \%$} & \multicolumn{2}{|c|}{$5 \%$} & \multicolumn{2}{|c|}{$1 \%$} \\
\hline $\mathrm{k}$ & $\mathrm{I}(0)$ & I (1) & $\mathrm{I}(0)$ & $\mathrm{I}(1)$ & $\mathrm{I}(0)$ & $\mathrm{I}(1)$ \\
\hline 5 & 2.43 & 3.50 & 2.78 & 3.94 & 3.57 & 4.84 \\
\hline & \multicolumn{4}{|c|}{ Computed F- test statistics } & \multicolumn{2}{|c|}{ p-value } \\
\hline \multicolumn{4}{|c|}{$F(($, pri $\mid m 2$, pui, lrgdp, rex,$r))$} & \multirow{2}{*}{$\begin{array}{l}5.227236 \\
1.386721\end{array}$} & \multicolumn{2}{|r|}{$(0.0017)^{*}$} \\
\hline \multicolumn{4}{|c|}{$F(m 2 \mid$ pri, pui, lrgdp, rex,$r)$} & & \multicolumn{2}{|r|}{$(0.2680)$} \\
\hline \multicolumn{4}{|c|}{$F($ pui $\mid$ pri, $\operatorname{lrgdp}$, rexm $2, r)$} & 1.442848 & \multicolumn{2}{|r|}{$(0.2456)$} \\
\hline \multicolumn{4}{|c|}{$F(\operatorname{lrgdp} \mid$ pri, $m 2, p u i, r e x, r)$} & 2.361586 & \multicolumn{2}{|r|}{$(0.0669)$} \\
\hline \multicolumn{4}{|c|}{$F($ rex|pri, $m 2, \operatorname{lrgdp}, p u i, r)$} & 1.929744 & \multicolumn{2}{|r|}{$(0.1252)$} \\
\hline \multicolumn{4}{|c|}{$F(r \mid p r i, p u i, m 2, \operatorname{lrg} d p, r e x)$} & 1.567546 & \multicolumn{2}{|r|}{$(0.2332)$} \\
\hline
\end{tabular}
significance, Results of $F$ - test for cointegration tests.

$\mathrm{K}$ - Stands for the number of regressors and critical values are obtained from pesaran et al...(2001).*indicates the cointegration among variables or rejection of the null-no cointegration among variables.
From the Table 2.3, above, using the F-statistic, the joint null hypothesis of lagged level variables (i.e. variables addition test) of the coefficients is zero, is rejected at all significance levels when private investment is taken as dependent variable. Since the calculated F-statistic for cointegration test which is $\mathrm{F}_{\mathrm{PRI}}=5.227236$ (when private investment supposed to be dependent or functions of other explanatory variables), exceeds the upper bound of the critical value at all levels of significance. Thus, the null hypothesis of no cointegration (i.e. no long-run relationship) between private investment and the explanatory variables is rejected at all significance levels.

When the other variables are taken as dependent variables the calculated F-statistics are less than the lower bound critical values, thus accepting the null of no cointegration with $\quad \mathrm{F}_{\mathrm{M} 2}=1.386721, \quad \mathrm{~F}_{\mathrm{pui}}=1.442848, \quad \mathrm{~F}_{\mathrm{rgdp}}=2.361586$, $\mathrm{F}_{\text {rex }}=1.929744$ and $F_{r}=1.567546$. Consequently, the result demonstrates that when private investment is the dependent variable, the null hypothesis of no cointegration cannot be accepted. Therefore, there exists a unique cointegration or long run relationship between private investment and its determinants or variables affecting the private investment.

The next task is to find out the long run coefficients following the ARDL approach to show the long run response of private investment to changes in each explanatory variable. 
Table 2.4. Estimated Long Run Coefficients using the ARDL Approach with 36 observations used for estimation from 1976 to 2011.

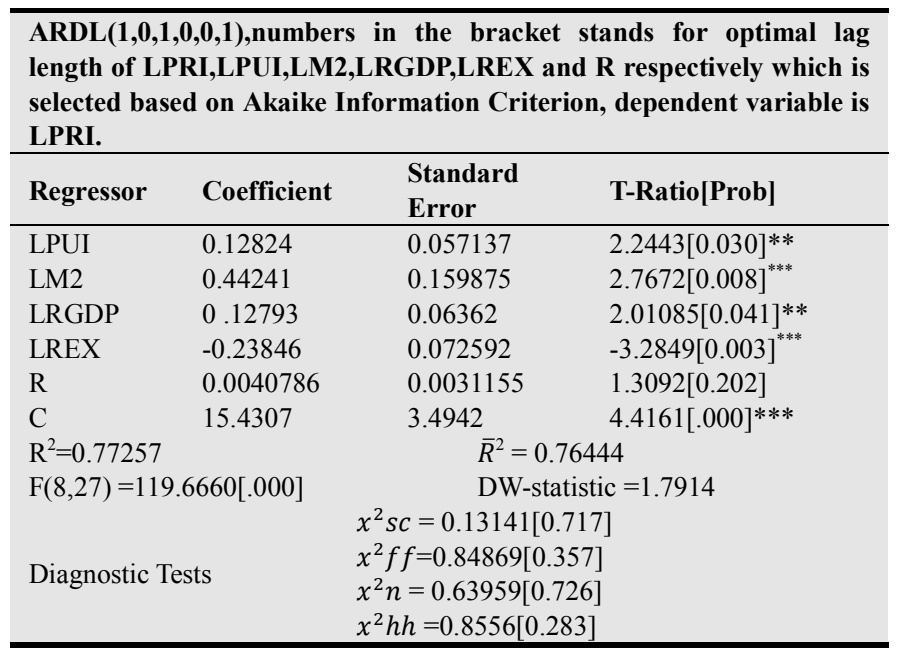

Note; $\left({ }^{* *}\right)$ and $(* * *)$ denotes significance at $5 \%$ and $1 \%$ level of significance. Since, the full result of the ARDL model is found in the appendix (table,5 in the appendix part). Where, $x^{2} s c, x^{2} n, x^{2} f f$ and $x^{2} h h$ stands for serialcorrelation, normality(Jarque-Bera), Ramsey RESET(functional misspecification),andheteroscedasticity tests respectively.

A number of diagnostic tests such as tests of serialcorrelation, normality, RESET (to cheek functional misspecification) and heteroscedasticity have been conducted.The estimated residuals did not provide any significant evidence of serial-correlation, non-normality and heteroscedasticity effect in the error term. Moreover, the Ramsey RESET test doesn't support the functional misspecification. Meanwhile, the adjusted R-squared of approximately 0.76 indicated that $76 \%$ of the variation in private investment was explained by the model. In addition to this, the estimated coefficients for the broad money supply satisfy the theoretical sign restrictions for log run models of ARDL.

However, model stability is necessary for prediction and econometric inference. Thus stability test has been conducted for estimated parameters by using the cumulative sum of recursive residual (CUSUM) and CUSUM of square (CUSUMSQ) tests. The results of the CUSUM and CUSUMSQ tests are reported in Figures 4.4 and 4.5 respectively as shown below. The test doesn't provide any evidence of instability in the estimates at the 5 percent significance level for conventional specification. Not only this but also the stability test shows that there is no significant structural break point in which the Chow Breakpoint test for the year 1991(which is suspected to have)shows that the $\mathrm{F}=1.433140$ (0.242324). Moreover, following a number of reforms under taken in 1992 and thus suspecting existence of breakpoint for this year, a similar test has been conducted yet the result didn't show the prevalence of breakpoint with $\mathrm{F}=1.457548(0.233485)$. Note that values in bracket stand for probability and F- denote the F- statistics.

Generally, the following graph shows stability of the model in which CUSUM and CUSUM squared of the residual is likely found in the $5 \%$ significance level.

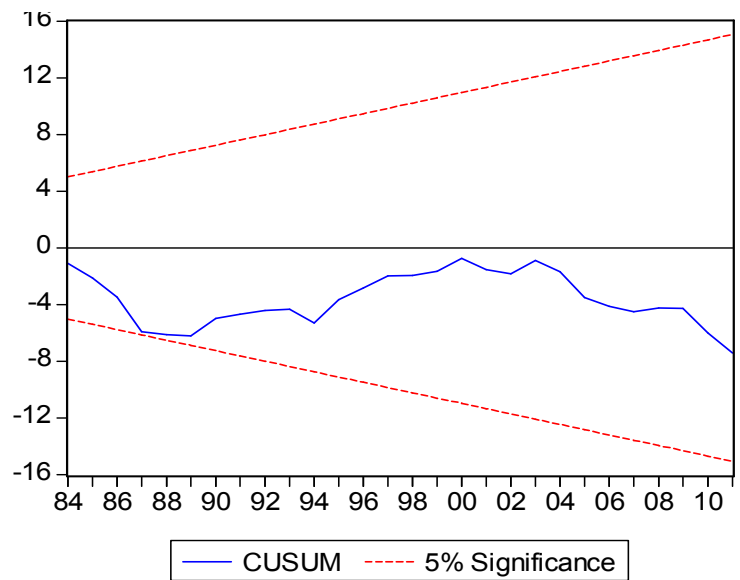

Figure2.1. cumulative sum of residual.

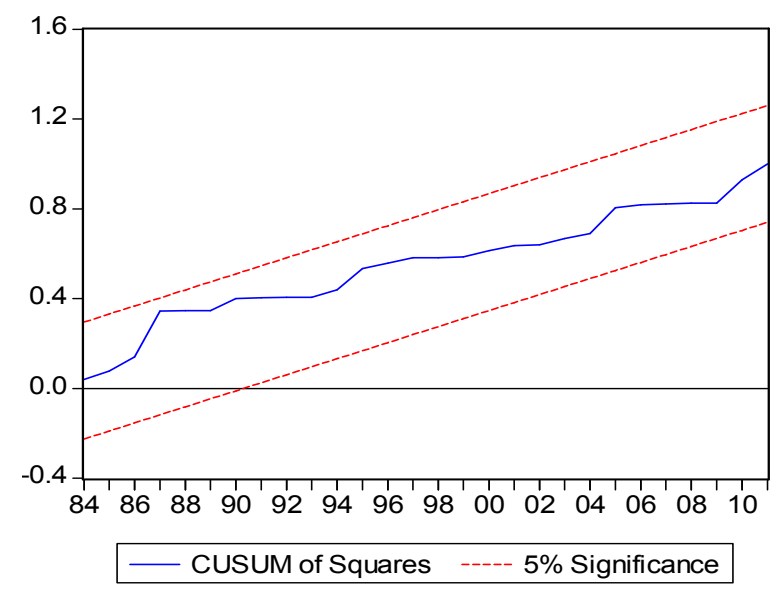

Figure2.2. cumulative of squares.

Therefore, following the test of stability of parameters in the long run, the model is developed from the table above (table, 2-4).

$$
\begin{gathered}
L P R I=15.43+0.13 L P U I+0.44 L M 2+0.12 L R G D P \\
-0.23 L R E X+0.004 R
\end{gathered}
$$

Lagged private investment (see the appendix) was also found to be positive and highly significant. Thus, past investments, which can be used as a proxy for the investment climate, constitute a good indicator for current investment decisions. A recent track record of private investment is expected to induce the private investor (especially the new investor) to invest more since this may be an indication of a good investment climate. Thus, lagged private investment has a positive impact on private investment.

The result shows that Public investment has a positive and significant coefficient at $5 \%$ confirming a possible crowdingin (complementary) effect of government investment in the long run. In which a $1 \%$ rise in public investment is potentially lead to a $0.13 \%$ increase in the private investment. This is due to that fact that the present government engage on infrastructural investments extensively such as roads and telecommunication to create conducive environment for investment. It is in line with the study of Greene (2000), 
Magnus (2010) that argued the complementary effect of public investment on private sectors. However, it contradicts with the result of Brian and Maganga (2012) arguing that public investment does not play any part in the determination of private investment.

The finding confirms the hypothesis that monetary policy is strongly influencing the private sector investment. From the result, the coefficient of broad money supply (M2) is statistically significant at 1 percent level, indicating that if the country were to increase its M2 by 1 percent, private investment will increase by 0.44 percent. Since Enterprises and industries are subject to liquidity constraints and information asymmetries: they are characterized by weaker balance sheets and are indeed more dependent on bank loans and on short-term debt.In addition, it is supported byEmpirical studies such as Eugenio (2001) that confirms the direct relationship between private investment and monetary policy. Moreover, the result is also in line with the study of Khan (2010).Thus, the credit views of monetary policy suggest that the tightening of monetary policy will force banks to reduce their loans and securities.

As a result, monetary policy is effective to vary the amount of commercial bank deposits using its instruments. A change in these deposits impacts on the interest rate at which credit is provided which in turn affects the growth of deposits held with commercial banks. Therefore, By increasing or reducing money supply the national bank of Ethiopia (NBE) effectively influences credit and thus private sector investment dependent on bank borrowing and hence a unitary expansionary of monetary policy implies that private investment will be raised by 0.44 percent according to the estimated long run equation through increasing the supply of credit held with commercial banks that will be used for investment.Thus, the correlation between money supply and private investment was found to be reliable.

Real GDP has the expected positive sign and it is significant in the long run and confirming the typical accelerator theory. As shown on the table(table,2.4), real GDP has a positive impact on private investment, confirming the results of Madsen, (2002), Booth (1999) and Wilson (2000) who argued that rapid growth leads to high rates of investment and vice versa. Consequently, the result confirms the accelerator theory of investment over the period 19752011 in Ethiopia. This means that in the long-run increases in real output or aggregate demand conditions has the potential of stimulating private investment. The result also confirms most findings in many empirical studies in the literature. Specifically, it concurs with studies by Ibrahim (2000), Asante (2000), Outtarra (2010), among other studies.

The long-run results reveal yet another intriguing outcome. Persistent depreciation of the domestic currency over the years coupled with devaluation at some point in time seems to have had a negative impact on private investment. A significant negative long-run association between private investment and real exchange rate was established at the $1 \%$ significance level. The implication is that depreciation of the Birr may be able to deter private investment for those industries which depend on import of capital goods.

Devaluation of the exchange rate might cause the cost of imported capital to increase, thus reducing private investment. Thus, it contradicts with the theoretical argument which states that depreciation and devaluation of domestic currency to have positive impact on private investment by boosting sectors investing on export and import substitution industries.For instance, Magnus (2010) and Asante (2000) find out that real exchange rate to have a positive impact on private investment.However, the result of this research work is supported by empirical findings of McCulloch (1999) and Maganga (2012) as devaluation seems to decrease private investment.

The McKinnon and Shaw (1973) "complementarity" hypothesis was confirmed in the case of Ethiopia contrary to the neoclassical theory of the user cost of capital as it has a positive coefficient.But it is insignificant. This is not a surprising to observe insignificant coefficient for the real interest rate for a developing country (Ethiopia) where structural constraints and under-developed financial markets are prevalent.

Once the long-run cointegrating model has been estimated, the next step is to model the short-run dynamic parameters within the ARDL framework. The table below (table2-5) presents the results of the estimated error-correction model of private sector investment model using the ARDL technique.

Table 2.5.Error Correction Representations for the Selected ARDL Model, $A R D L(1,0,1,0,0,1)$, the numbers in the bracket denotes lag orders of the variables,selected based on Akaike Information Criterion.Dependent variable is dLPRI, 36 observations used for estimation from 1976 to 2011.

\begin{tabular}{llll}
\hline Regressor & Coefficient & $\begin{array}{l}\text { Standard } \\
\text { Error }\end{array}$ & T-Ratio[Prob] \\
\hline dLPUI & 0.2913 & 0.1396 & $2.0865[.0403]^{* *}$ \\
dLM2 & 0.47807 & 0.2306 & $2.070[.0467]^{* *}$ \\
dLRGDP & 0.0911 & 0.035 & $2.581[.0055]^{* * *}$ \\
dLREX & -0.169 & 0.0584 & $-2.90[.007]^{* * *}$ \\
dR & -0.0412 & 0.19338 & $-0.213[0.833]$ \\
ecm $(-1)$ & -0.7126 & 0.1351 & $-5.27[.000]^{* * *}$ \\
ecm $=$ LPRI- $.12824 *$ LPUI- $.44241^{*} \mathrm{LM} 2-.12793 *$ LRGDP \\
$+.23846 *$ LREX-.0040786*R- $15.4307 * \mathrm{C}$ \\
$\mathrm{R}^{2}=0.65028$ & $\mathrm{DW}=1.89$ \\
$\overline{\boldsymbol{R}}^{2}=0.61702$ & $\mathrm{~F}(6,29)=5.5061[.001]$ \\
\hline
\end{tabular}

Note; $(* *),(* * *)$ indicates significance of coefficients at $5 \%$ and $1 \%$ respectively.

Table 2.6.Diagnostic tests for the short run models (error correction model).

\begin{tabular}{ll}
\hline Breusch-Godfrey Serial & $x^{2}=1.955515(0.163390)$ \\
Correlation LM Test & $x^{2}=0.629456(0.729987)$ \\
ARCH Test & $x^{2}=1.49444(0.235481)$ \\
Jarque-Bera & \\
\hline
\end{tabular}

Consistent with the long run tests, the diagnostic test carried out for the short run model does not provide any evidence against the absence of serial correlation, Auto-correlation conditional heteroscedasticity (ARCH effect) and normality (normal distribution of the residual).

Crowding-in effect of public investment on private investment is confirmed in the short-run as the coefficient of public investment is statistically significant at the 5 percent significance level. This is in contrast with that of Acosta 
(2000) that confirms the crowding-out effect of public investment. Acosta (2000) suggests that there is a sort of competition for resources between the public and the private sectors, at least in the short run. But in this paper, the result ensures that there is a positive and a complementary relationship between private investment and public investment. Since the government financed most of its expenditures via foreign aid and loans from abroad and hence there may not a significant tax burden on the private sector rather the government extensively investing on road constructions, real estate, telecommunications, human development(education and health) etc which enable the progress of private sector investment.

It is also evidenced that the result validates the hypothesis of positive impact of money supply on private sector investment in the short run. The temporal effects of money supply estimated at 0.48 percent entails a significant positive impact on private investment. When money supply increases, with extra money circulating within the economy, the purchasing power of all sectors that is households, business and government is enhanced. Thus, consumption expenditures, investment expenditures, government purchases all increases, resulting in an increase in aggregate demand and hence investment.

Changes in money supply can have an impact on the private investment through transmission channels of credit facilities. Since in an environment where some economic agents are constrained in their capacity to spend by their currently available income and liquid assets, an easier access to funds will increase real consumption and real investment expenditures. The empirical support is provided by World Bank (WB, 2009).Moreover, an increase in money supply improves banks' capital positions and may increase their capacity to expand theirasset holdings, thereby potentially inducing a leveraging process.

Consistent with the long-run results, the coefficient of real GDP has the theorized positive and significant impact on private investment in the short-run. That is, output growth induced crowding-in effects and supports typical of its accelerator characteristics.

The result shows that the effect of exchange rates on private investment is statistically significant at $1 \%$. Real exchange rate depreciation has a negative and significant effect on private investment in the short run. This presupposes that the tradable sectors and import substitution industries detriment from the depreciation of the domestic currency over the period under consideration as they used imported capital goods which become expensive after policy changes. It is contradicted with empirical investigation of Chichi (2011) showing positive impact of real exchange rate on private investment. But it is in line with the empirical analysis of Acosta (2005) in which a devaluation seems to decrease investment substantially. Thus, real exchange rate change seemed to have had an adverse effect on short term investment, affecting mainly the sectors most exposed to foreign competition (non-exportable) and increases cost of production.
However, it is also in contradict with Tarek (2005) in which he find out that depreciations would have a positive effect on private sector investment. It is theoretically, obvious that when a currency depreciates, it reduces the country's wages and production costs relative to those of its foreign counterparts. All else equal, the country experiencing real currency depreciation has enhanced locational advantage or attractiveness and receives productive capacity investments from abroad. By this the exchange rate depreciation improves the overall rate of return to foreigners contemplating an overseas investment project in the country. Thus it would enhance foreign direct investment. But all this would happen at the expense of domestic investment due to increase in cost of production. However, for Ethiopian case, In effect exchange rate has significant negative effect on private investment.

In contrast to the long run, in the short run the user cost of capital that is Interest rate seems to work against private investment. However, it is insignificant to influence the sector. Moreover, the insignificant behavior of real interest rate may reveal the under developed nature of financial markets. The empirical support is provided by Greene (2000) though it is in contrast with the study of Bader (2010) who shows that an increase in real interest rate has a positive effect on private investment.

The error correction term is negative and significant at 1 percent level of significance suggesting that private sector investment adjusts to deviations from its long term equilibrium. This means that 71 percent of last year's disequilibrium is corrected by changes in private sector investment. Or it suggests that, about 71 percent of the discrepancy between the actual and long run values of private investment is corrected within each year.

\section{Conclusion and Policy Implication}

\subsection{Conclusions}

Drawing on relevant theoretical foundations and empirical research done for most developing countries, this study set out to empirically reveal the impact of monetary policy on private investment in Ethiopia during the period 1975-2011. By employing time series econometric techniques, the study sought to obtain robust and consistent models capable of providing vital information. Empirical findings obtained in the long-run showed that there is no doubt that monetary policy is a key and can be considered as engine for the progress of private sector investment in Ethiopia. This is because of the fact that the long-term effect of money supply on private sector investment displays the expected coefficient signing from theoretical literature. Moreover, Money supply was found to be effective monetary policy instrument than the interest rate. This is based on the fact that private investment react more to changes in money supply than the interest rate does.

The significant positive impact of public investment on private investment in the short-run and long run indicates an 
important complementary role played by the government in boosting private sector investments. The study also confirms the accelerator theory because GDP, that represents the aggregate demand condition, is found to have a positive relation with private investment both in the short run and long run. Thus, the positive and significant coefficient of real GDP confirms the typical accelerator theory of investment in our case.

Private investment responds negatively to changes in real exchange rate both in the short run and long run.Moreover, the user cost of capital (real interest rate) is insignificant to have real effect.

In general the result assured that monetary policy is more influential and powerful than fiscal policy in boosting private investment as the coefficient of money supply (LM2) is by far greater than public investment (LPUI) in the econometrics result.

\subsection{Policy Implications}

As monetary policy and private investment are strongly correlated both in the long run and short run, and hence using contractionary policy to curb inflation rate may deprive the performance of the sector. Thus, it is better to use other way of controlling inflation rate such as improving the performance of supply sides (productivity to match with the growing demand conditions).Moreover, following the positive relationship between public investment and private sector, it is essential for the government to continue establishing its public projects. Therefore, in line with the
Government's overall growth framework, the development of basic infrastructures will certainly yield the desired objective of promoting the performance of private investment.

A fluctuation in the real exchange rate is seen to have an adverse effect on private investment both in the short and long run. This is not surprising as depreciation (devaluation) of the exchange rate raises the cost of capital importation in local currency terms. As a developing country, Ethiopia depends on imported capital assets for investment purposes. Thus, Exchange rate Stabilization policy should therefore be put in place as a mechanism to remedy the adverse effect of exchange rate depreciation on private investment. One possible way of stabilizing the exchange rate could be through the indirect intervenes of the government by selling or buying foreign currency whenever there is disequilibrium in the foreign exchange market.

However, this paper is conducted at aggregate level (macro level), thus, more future studies need to be done at micro level in an effort to complement the empirical evidence presented by this study. Moreover, from the study, though most of the listed variables are significant, they together account small proportion of the behavior of private sector investment. Consequently, there seem other factors such as external shocks, which potentially bring real effects on private sectors, official attitude towards private investors and lack of credibility in government policies may be some of the factors that necessitate future research works as well.

\section{Appendices}

Table 1.Correlation matrix.

\begin{tabular}{lllllllll}
\hline & LPUI & LPRI & LM2 & LDCP & IF & LREX & LRGDP & R \\
\hline LPUI & 1 & 0.77 & 0.69 & 0.92 & 0.74 & -0.69 & 0.54 & 0.03 \\
LPRI & 0.77 & 1 & 0.94 & 0.89 & 0.13 & -0.70 & 0.89 & 0.11 \\
LM2 & 0.69 & 0.94 & 1 & 0.94 & 0.70 & -0.71 & 0.65 & 0.06 \\
LDCP & 0.92 & 0.89 & 0.94 & 1 & 0.161 & -0.85 & 0.92 & 0.09 \\
IF & 0.74 & 0.13 & 0.70 & 0.16 & 1 & 0.52 & 1 & -0.81 \\
LREX & -0.69 & -0.70 & -0.71 & -0.85 & 0.52 & -0.64 & -0.28 \\
LRGDP & 0.54 & 0.89 & 0.65 & 0.92 & 0.81 & -0.64 & -0.28 & 1 \\
R & 0.03 & 0.11 & 0.06 & 0.09 & -0.77 & -0.28 & 0.005 & 1 \\
\hline
\end{tabular}

Table 2. Pair wise Granger Causality Tests among variables.

\begin{tabular}{llllll}
\hline cause & & & & \\
\hline Effect & LPRI & LPUI & R & LREX & LRGDP \\
\hline LPRI & $1.17(0.32)$ & $1.11(0.34)$ & $0.38(0.68)$ & $0.40(0.67)$ & $1.57(0.22)$ \\
LPUI & $0.94(0.39)$ & $0.13(0.87)$ & $0.14(0.86)$ & $4.34(0.02)$ & $0.79(0.45)$ \\
R & $0.84(0.43)$ & $0.37(0.68)$ & $1.41(0.25)$ & $1.45(0.24)$ & $0.24(0.78)$ \\
LREX & $1.56(0.22)$ & $0.24(0.78)$ & $1.84(0.17)$ & $2.14(0.13)$ & $0.14(0.86)$ \\
LRGDP & $0.25(0.77)$ & $0.63(0.53)$ & $0.16(0.84)$ & $1.9(0.15)$ & $1.57(0.22)$ \\
LM2 & $2.98(0.06)$ & $3.42(0.04)$ & $4.08(0.02)$ & $3.37(0.04)$ & $0.99(0.38)$ \\
\hline
\end{tabular}

Note: the null hypothesis is that variables in the first column don't cause variables in the first row and numbers in bracket stands for probability. 
Table 3.critical value of the bound test of Pesaran (2001) with intercept and no trend.

\begin{tabular}{lllllll}
\hline & $\mathbf{1 0} \%$ & & $\mathbf{5 \%}$ & & $\mathbf{1 \%}$ & \\
\hline $\mathbf{K}$ & $\mathbf{I}(\mathbf{0})$ & $\mathbf{I}(\mathbf{1})$ & $\mathbf{I}(\mathbf{0})$ & $\mathbf{I}(\mathbf{1})$ & $\mathbf{I}(\mathbf{0})$ & $\mathbf{I}(\mathbf{1})$ \\
\hline 0 & 7.60 & 7.60 & 9.20 & 9.20 & 12.88 & 12.88 \\
1 & 4.54 & 5.27 & 5.43 & 6.24 & 7.41 & 8.37 \\
2 & 3.51 & 4.46 & 4.13 & 5.16 & 5.50 & 6.67 \\
3 & 2.97 & 4.00 & 3.49 & 4.58 & 4.56 & 5.83 \\
4 & 2.65 & 3.71 & 3.07 & 4.19 & 3.95 & 5.24 \\
5 & 2.43 & 3.50 & 2.78 & 3.94 & 3.57 & 4.84 \\
6 & 2.27 & 3.36 & 2.60 & 3.75 & 3.29 & 4.56 \\
7 & 2.16 & 3.25 & 2.45 & 3.61 & 3.07 & 4.39 \\
8 & 2.06 & 3.17 & 2.34 & 3.56 & 2.91 & 4.19 \\
9 & 1.98 & 3.08 & 2.24 & 3.39 & 2.76 & 4.05 \\
10 & 1.92 & 3.02 & 2.16 & 3.32 & 2.63 & 3.94 \\
\hline
\end{tabular}

Table 4.Autoregressive Distributed Lag Estimate, ARDL (1, 0, 0, 0, 1, 1) selected based on Akaike Information Criterion, Dependent variable is LPRI, 36 observations used for estimation from 1976 to 2011.

\begin{tabular}{llll}
\hline Regressor & Coefficient & Standard Error & T-Ratio[Prob] \\
\hline LPRI(-1) & .28740 & .13519 & $2.1258[.043]$ \\
LPUI & .091382 & .04125 & $2.2153[.035]$ \\
LRGDP & .091165 & .04520 & $2.016925[.0506]$ \\
LREX & -.16993 & .058419 & $-2.9088[.007]$ \\
LM2 & .13486 & .044031 & $3.0628[.0057]$ \\
LM2(-1) & .50504 & .26210 & $1.9269[.065]$ \\
R & $.4122 \mathrm{E}-3$ & .0019338 & $.21314[.833]$ \\
R(-1) & .0033186 & .0019098 & $1.7377[.094]$ \\
C & 10.9960 & 2.9396 & $3.7407[.001]$ \\
$\mathrm{R}^{2}=0.77257$ & $\bar{R}^{2}=0.76444$ & \\
F(8,27)=119.6660[.000] & DW-statistic $=1.7914$ \\
& $x^{2} s c=0.13141[0.717]$ \\
Diagnostic Tests & $x^{2} f f=0.84869[0.357]$ \\
& & $x^{2} n=0.63959[0.726]$ \\
& $x^{2} h h=0.8556[0.28]$ \\
\hline
\end{tabular}

Note, Where, $x^{2} s c, x^{2} n, x^{2} f f$ and $x^{2} h h$ stands for serial-correlation, normality(Jarque-Bera), Ramsey RESET(functional misspecification), and heteroscedasticity tests respectively.

\section{References}

[1] Abebe A. (2008), Excess Liquidity and Effectiveness of Monetary Policy: Evidence from sub-Saharan Africa, IMF, WP $/ 06 / 115$.

[2] Acosta P.(2000), short and long run determinants of private investment in Argentina, journal of applied economics, vol.8, no. 2

[3] Alatiqi S, (2008) "can money supply predict stock prices?”journal for economic educators, vol.8, no. 2

[4] Alexander D. (2011), the long run relation between monetary policy and private investment in Nigeria, research journal of finance and accounting, Nigeria.

[5] Alexiadis S. and Daniel F. (2012), the flexible accelerator model and the regionalization of capital stock, regional science inquiry journal, vol.4, Attens, Greece

[6] AM Sisay, (2007),Determinants of Private Investment in Ethiopia: A Time Series Study American Economic Association
[7] Angeloni, I.(2003), Monetary Policy Transmission in the Euro Area, Cambridge University Press

[8] Asante Y. (2000), Determinants of privateinvestment behavior, AERC Research Paper, African Economic Research Consortium, Nairobi. Kenya.

[9] Asante, Y.,(2012), Government Policy and Private Investment in Developing Countries, IMF working papers, vol,6,no.2

[10] Asrat S. (2012), "does the Ethiopian economy take after Asian growth?" a working paper.

[11] Axilrod, H. (1997), 'Transformation to Open Market Operations;' Developing Economies and Emerging Markets, Economic issues, IMF, Washington

[12] Ayemere I.(2010) monetary policy and investment in Nigeria.

[13] Bajide N. (2011), "Capital Controls and Monetary Policy in Developing Countries", IMF working papers

[14] Booth, A. (1999). Initial Conditions and Miraculous Growth: Why is South East Asia Different from Taiwan and South Korea? World Development, Vol. 27, No. 2.

[15] Bruno M. (2001), an econometric analysis of private sector investment in Brazil, department of economics, university of Brasilia, a journal on cepal review,

[16] Chibber, A. and D. Mansoor (2001),"Fiscal policy and private investment in developing countries". RechercheEconomique, XLIV

[17] Chichi A. (2009), The Impact of Monetary Policy on MicroEconomy and Private Investment in Nigeria, Research Journal of Finance and Accounting, Vol 1, No 3.

[18] Chichi A. (2011) Long Run Relationship between Private Investment and Monetary Policy in Nigeria, Journal of Finance and AccountingVol 2, No 6

[19] Daniel Z. (2008), 'Determinants of private investment in Ethiopia'. Economic Review, American Economic Association Economics,

[20] Davison W. (2012), "Ethiopian central bank looser monetary policy to boost lending", Annual report

[21] Dickinson D. (2005), the real effect of monetary policy in china, an empirical analysis, china economic review

[22] Ezie O. (2012), an empirical analysis of monetary policy and private sectored investment in Nigeria, department of economics, Bingham University, KaruNasarawa state, Faculty of Social Sciences, University of Cape Coast

[23] Fikru D. (2007), the analysis of behavior of private investment in response to fiscal policy changes in sub-Saharan Africa, Addis Ababa University, Ethiopia

[24] Genevesi O. (1997), A Statistical Analysis of Foreign Exchange Rate Behaviour in Nigeria's Auction

[25] Getinet,A.(2005), 'Determinants of Foreign Direct Investment in Ethiopia:' A time-series analysis, Paper prepared for the 4th International Conference on the Ethiopian Economy.

[26] Godwin c. (2010), government expenditure, money supply, prices and output relationship in Nigeria: an econometric analysis, International research journal of finance and economics, Euro journals publishing, Inc, Issue 54. 
[27] Greene, J., (2000), Private investment in developing countries: an empirical analysis. IMF Staff Papers, 38 (1)

[28] Hall R. and hitch (1989) price theory and business bevior, oxford economic papers

[29] Handa J. (2009), "Monetary Economics", 2nd Edition, McGill University, Canada.

[30] Imtiaz A. (2012) dynamic modeling of private investment in agricultural sector of Pakistan

[31] J.Manuel (1998) Investment, Pass-Through, and Exchange Rates: A Cross-Country Comparison

[32] John J. (2010), "how falling exchange rates 2000-2007 have affected the U.S. economy and trade deficit", New York, USA.

[33] Karagoz K. (2010), determining factors of private investment, an empirical analysis for turkey.

[34] Khan M., (1999), "Private Investment and Economic Growth in developing Countries" IMF Staff Papers

[35] Khan, (2010), Crowding Out Effect of Public Borrowing: A Case of Pakistan, TheIslamia University of Bahawalpur, Pakistan, MPRAPaper.

[36] Liang F. and Huang W. (2011), the relationship between money supply and the GDP of USA, Maganga A. (2012), selected macro economic variables affecting private investment in Malawi, Munich personal RPEC archive (MPRA).

[37] Maganga A. (2012), selected macro economic variables affecting private investment inMalawi, Munich personal RPEC archive (MPRA).

[38] Madsen J. (2002), The Causality Between Investment and Economic Growth, Economics Letters

[39] Magnus J. (2010), The Determinants of Private Sector Investment in Ghana: An ARDL Approach, European journal of social sciences, vol.15, no.2, Accra, Ghana.

[40] McCallum B. (1999), "targets versus instrument rules for monetary policy', federal reserve bank of st. Louis reviews.

[41] McKinnon, R.I. (1998), 'Money and Capital in Economic Development', Washington DC: The Brookings Institution.

[42] Michelle c. (2002), investment in uncertain world, Zagreb international review of economics and business, vol.5, n0.1, Croatia

[43] Misati R.(2010), liberalization, stock market development and investment efficiency in Africa, The African Economic and Business Review, Vol. 3, No. 1
[44] Mongbay, (2010), 'Ethiopian banking and monetary policy', country specific

[45] Nayaran, P.K., (2004), "The saving and investment nexus for China: evidence from cointegration tests", Applied Economics, Vol. 37.

[46] National bank of Ethiopia (2009), NBE's monetary policy frame work, Addis Ababa, Ethiopia

[47] Nouri M.(2011), The Impact of Monetary Policy on Economic Growth in Iran, Middle East journal of scientific research 9(6), Babolsar, Iran

[48] Olweny ,(2007), Macroeconomic Development and Private Sector Performance in Ethiopia: The 1990's Experience, working papers

[49] Olweny T. (2012), the effect of monetary policy on private sector investment in Kenya, journal of applied finance and banking,vol.2.no.2, international scientific press, Kenya.

[50] Ouattara B. (2010), Modeling the Long Run Determinants of Private Investment in Senegal, school of economic studies, university of Manchester.

[51] Pesaran M.H and R.J. Smith (2001), "bound testing approaches to analysis of long run relationship", journal of applied econometrics

[52] Rufus A. (2008), optimizing macroeconomic investment decisions; a lesson from Nigeria, European Journal of Scientific Research, ISSN 1450-216X Vol.22 No.4

[53] Sengonzi F. (2009) the relative efficiency effectiveness of fiscal and monetary policy in macroeconomic management

[54] Shaw, E. (1998), Financial Deepening in Economic Development,: Oxford University Press

[55] T.K. Jayaraman, (2008), Monetary Policy Transmission Mechanism in Fiji: An Empirical Analysis of The Quarterly Model, international journal of business and management, vol.3, no. 11

[56] TadesseA. AndTekie A. (2012), Adjustment and the effectiveness of monetary policy in Ethiopia

[57] Tarek H. (2005) The Effects of the Exchange Rate on Investment: Evidence from Canadian Manufacturing Industries, Bank of Canada Working Paper

[58] William R.(2004), 'monetary policy actions and the incentive to invest", working paper series.

[59] Wilson, E.J. (2000). Savings, Investment, Productivity and Economic Growth of Australia 1861- 1990: Some Explorations. The Economic Record. 